\title{
Potential Loss in Soybean Yield Due to Root-Knot Nematode, Meloidogyne Arenaria in Sandy Soil
}

\author{
A.M. Korayem ${ }^{*}$ and M.M.M. Mohamed \\ * Plant Pathology Department, National Research Centre, Dokki, Egypt.
}

\begin{abstract}
During 2015 summer season, relationship between the root-knot nematode damage (root galling) and growth and yield of soybean was studied in a field of sandy soil naturally infected with Meloidogyne arenaria for showing the effect of nematode infection on soybean yield. At soybean harvest, about 100 plants were randomly selected for assaying their root galling (damage) and yield. Top shoot weight and seed yield were negatively correlated with nematode damage with highly correlation coefficient $(r)-0.97$ in case of shoot weight and-0.96 in case of seed yield. Observed loss in the top shoot weight was $36.47 \%$ and was $44.7 \%$ in seed yield at severely damage (GI-5). While the expected loss was $38.7 \%$ and $46.5 \%$ for shoot and seed yield, respectively.
\end{abstract}

Key words: Soybean, root-knot nematodes damage, yield loss.

\section{Introduction}

Soybean (Glycine max L.) was introduced to Egypt more than 50 years ago, but its commercial cultivation has been begun during the two last decades (Kella et al., 2011). Now it is successfully grown as an early summer crop in different localities of Egypt. Soybean is considered one of the important food crops for human and animals, so its cultivation rapidly increased in many parts of the world. Value of soybean depends the seed oil content which is ranged from $19-22 \%$ (Harry and Kown, 1987) and protein content that ranged from 30-50\% (Singh et al., 1987).

The root-knot nematodes Meloidogyne spp. are of great economic and social importance, being serious plant pathogens worldwide distribution infecting a wide range of crops causing loss up to $80 \%$ in heavily infested fields with average yield losses ranging from $28 \%$ to $68 \%$ (Chaudhary et al., 2011). Thus they are considered one of major limiting factors in the production field and plantation crops, predominantly in warmer climatic but also in temperate regions (Riggs \& Niblack, 1993; Jepson, 1987; Siddiqi, 2000). Soybean plants had been early included in the list of plants which are infected with the root-knot nematodes Meloidogyne species (Goodey et al., 1965). The root-knot nematodes. M.incognita, M.javanica and M.arenaria are dominant in warmer climatic regions and cause great losses in soybean yield, so they are important factors limiting soybean production (Schmitt 
and Noel, 1984). Loss in soybean yield was estimated by $90 \%$ due to M.incognita in Florida (Kinloch, 1974). In the USA and Canada (Ontario), over 93000 metric tons of soybean were lost annually between 1999 and 2002 due to Meloidogyne species (Wrather et al., 2003). Also in Gorgea State, the yield of soybean grown in fields naturally infested with the root-knot nematodes treated with DBCP nematicide, increased by $48.1 \%$ (Minton, 1979). Recently during years of 20032005 the combined soybean yield loss due to Meloidogyne species and all other phytonematodes was ranged between 106 to 139 thousand tons in USA (Noel, 2008).

In Egypt many reports indicated that soybean plants are infected by the rootknot nematodes Meloidogyne spp. (El-Sherif and Ismail, 2011; Ibrahim, 2011). Most studies were done on effect of root- knot nematodes on vegetative growth parameters in pot experiment. Growth parameters of soybean were inhibited due to M.incognita by $37.3 \%, 31.9 \%$ and $42.8 \%$ for length, fresh weight of plants and number of leaves per plant, respectively (El-Sherif et al., 2012). Still loss in soybean yield due to root-knot nematodes is not yet accurately determined specially in natural infested fields of Egypt.

Estimating yield loss of a such crop due to root-knot nematodes can be determined by relating the yield with the nemoatode population in soil at planting or by relating the yield with the root knot severity (nematode damage). Relating between different nematode populations densities in the soil at planting and yield of plants is a good method for estimating the nematode threshold population levels (damage threshold, tolerance limit and economic threshold) including the yield loss (Seinhorst, 1965). But a reliable estimation of root-knot nematode population density in a natural field at planting is so difficult because (1) the spatial distribution of nematodes in the field is heterogeneous, (2) the egg masses remain intact in the soil free or attached to root fragments of the previous host, thus majority of soil analysis methods used will not always detect the egg masses in field with low rootknot infection (Netscher and Sikora, 1990). An accurate estimation of yield loss can be obtained by relating the crop yield with the root-knot severity at the end of vegetative period of plants (shortly before harvest). Therefore, the objectives of the present work were (1) to relate the yield of soybean with the root-knot damage (severity of root galling) at harvest for calculating yield loss caused by nematodes,

(2) to depict the nematode damage-yield curves for estimating the expected yield loss.

\section{Materials and Methods}

\section{Location of the study:}

The experiment was conducted during 2015 summer season in a field of sandy soil naturally infested with root-knot nematode at the Experimental Station of 
National Research Centre, Nobaria Distruict, El-Beheira governorate, Egypt.

\section{Test nematode:}

The adult females of Meloidogyne were collected from the infected soybean roots at harvest. Then were identified according to the morphology of their perineal pattern (Hunt and Handoo, 2009).

\section{Test plant and layout of the experiment:}

Seeds of soybean cv. Giza-21 which was previously categorized as susceptible cultivar (El-Sherif et al., 2012) were obtained from Legume Research Department, Field Crops Research Institute, Agriculture Ministry. Area of the experiment about $4000 \mathrm{~m}^{2}$, was prepared before planting in rows of $50 \mathrm{~cm}$ width. Seeds were planted in hills at rate of 2-3 seeds per hill in 1-5-2015. Mixture of calcium superphosphate $\left(15 \% \mathrm{P}_{2} \mathrm{O}_{5}\right)$ at rate of $400 \mathrm{~kg} / \mathrm{h}$ and potassium sulphate $\left(48.5 \% \mathrm{~K}_{2} \mathrm{O}\right)$ at rate of $200 \mathrm{Kg} / \mathrm{h}$ was added during seed bed preparation. Ammonium nitrate $(33.5 \% \mathrm{~N})$ at rate of $400 \mathrm{Kg} / \mathrm{h}$ was added in two equal portions one and two months after seed germination.

\section{Nematode damage assaying:}

Shortly before harvest (12-9-2015) more than one hundred soybean plants were randomly selected, and processed for assaying severity of nematode damage (root gall indices, GI) according to Barker (1985) as follows: 1= no galls, 2=1-25\% galls, $3=26-50 \%$ galls, $4=51-75 \%$ galls, $5=76-100 \%$ galls.

\section{Soybean growth and yield assessment:}

Same selected plants were also processed for determining their fresh shoot weights and seed yield.

\section{Statistical analysis:}

Data were subjected to analysis of variance (ANOVA) and averages of fresh shoot weights and seed yield per plant were compared according Tukey test (Neler et al., 1985). Relationships between root-gall indices (GIs) and soybean growth and yield were depicted as regression lines for derivation linear and quadratic equations and for determination correlation coefficient $(r)$ between nematode infestation and soybean growth and yield.

\section{Results}

Data presented in Table (1) indicated that growth and yield of soybean (cv. Giza -21) were significantly influenced by the nematode infection (root-galling). Significant reductions $(P=0.05) 12.66 \%, 31.66 \%$ and $36.47 \%$ in top shoot weight of plants were occurred at 3,4 and 5 root gall indices, respectively, while at GI-2 no significant reduction was obtained. Also, seed yield per plant was significantly reduced by $13.5 \%, 39.3 \%$ and $44.7 \%$ at $\mathrm{Gl} 3,4$ and 5 , respectively. A lower 
infection (Gl-2), seed yield was not affected. Root gall indices (Gls) were plotted against the shoot weight per plant (Fig. 1) and seed yield per plant (Fig. 2) for depicting the regression lines. Data showed that the relationship between nematode infection and both growth and yield of soybean were negative with high correlation coefficient ( $r$ ) -0.98 in case of shoot weight and -0.97 in case of seed yield. According to the quadratic equation, the expected loss of soybean severely infected with nematodes $(100 \%$ root galling $=$ GI-5) were more than loss obtained from the experiment. Expected loss in shoot weight was $38.7 \%$ and it was $46.5 \%$ in case of seed yield (Table -1$)$.

Table (1): Relationship between M.arenaria root galling and growth and yield of Giza -21 soybean.

\begin{tabular}{lcccccc}
\hline $\begin{array}{c}\text { Root gall } \\
\text { index (GI) }\end{array}$ & $\begin{array}{c}\text { Fresh shoot } \\
\text { weight g/plant }\end{array}$ & $\begin{array}{c}\text { Red. } \\
\%\end{array}$ & $\begin{array}{c}\text { Expected }^{*} \\
\text { reduction\% }\end{array}$ & $\begin{array}{c}\text { Seed yield } \\
\text { g/plant }\end{array}$ & Red \% & $\begin{array}{c}\text { Expected * }_{\text {reduction \% }} \\
\text { reduct }\end{array}$ \\
\hline 1 & 97.9 a $(\mathrm{n}=18)$ & - & - & $97.6 \mathrm{a}$ & - & - \\
2 & $95.0 \mathrm{a}(\mathrm{n}=17)$ & 2.96 & 5.6 & $89.5 \mathrm{a}$ & 8.3 & 8.2 \\
3 & $85.5 \mathrm{~b}(\mathrm{n}=20)$ & 12.66 & 14.8 & $84.4 \mathrm{~b}$ & 13.5 & 19.2 \\
4 & $66.9 \mathrm{c}(\mathrm{n}=19)$ & 31.66 & 25.8 & $59.2 \mathrm{c}$ & 39.3 & 31.9 \\
5 & $62.2 \mathrm{c}(\mathrm{n}=18)$ & 36.47 & 38.7 & $55.0 \mathrm{c}$ & 44.7 & 46.5 \\
\hline
\end{tabular}

$\mathrm{n}$ : Number of replicates.

Means having different letter are significantly $(P=0.05)$ according to Tukey test.

* Based on the quadratic regression equations.

\section{VAR00002}

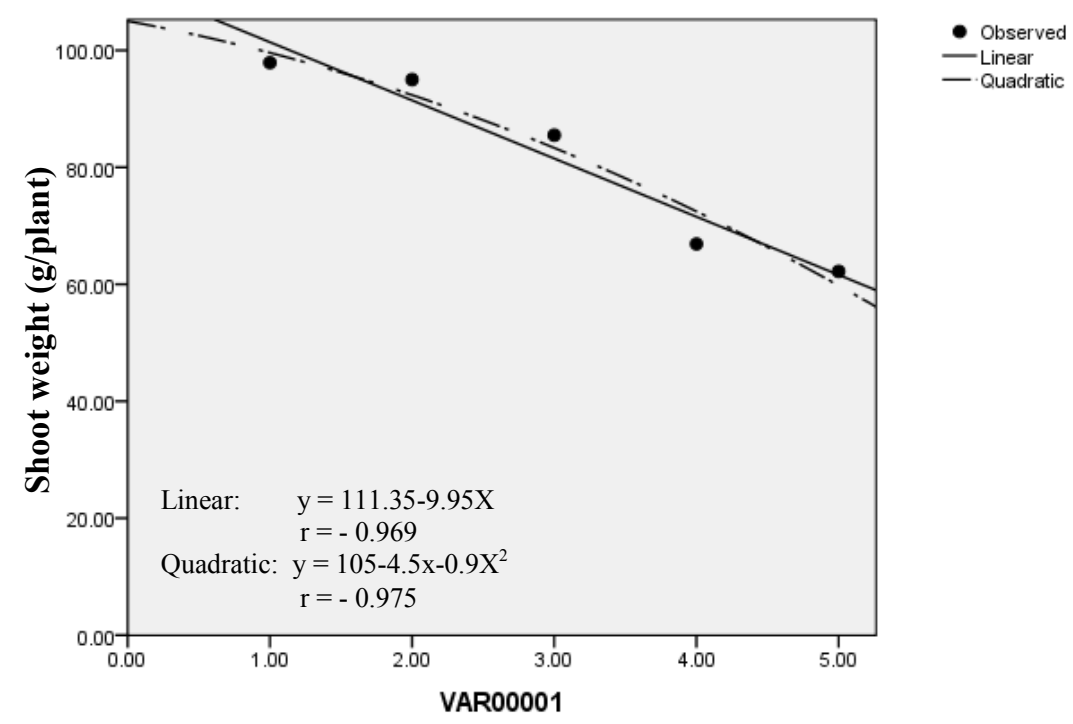

Nematode root-gall index

Fig. (1): Relationship between nematode root-gall index and the top fresh shoot weights of soybean. 


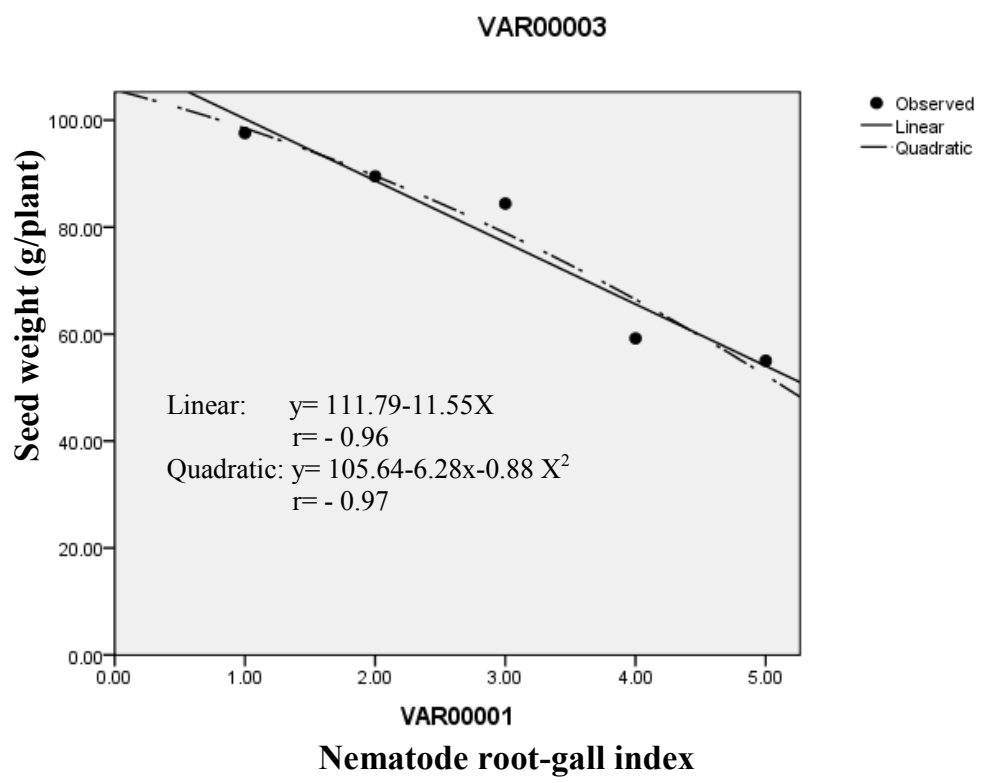

Fig. (2): Relationship between nematode root-gall index and seed weight of soybean.

\section{Discussion}

Information on the extent of damage the nematode may cause to plant yield, especially the yield loss, is basic in making management decisions. In the present study, observed loss in soybean yield caused by the root knot nematode M.arenaria under natural infestation was estimated at harvest stage. Relationship between nematode damage (root galling) and yield was depicted as linear and quadratic regressions, then expected loss in soybean was assessed. Determination of loss in yield caused by the root knot nematodes by relating severity of root galling at harvest with yield may be more accuracy than determination of yield loss by relating the initial nematode population $(\mathrm{Pi})$ before planting with yield. Since estimation of nematode density in soil before planting is difficult because reasons which previously mentioned in the introduction, moreover in many cases, plants at harvest were found to be heavily galled (infected) still soil nematode analysis was negative at planting ie soil was nematode free.

Our data suggested that soybean cv. Giza-21 is infected with the root-knot nematode M.arenaria, and its yield is subjected to great reduction. As the top shoot weight and seed yield were reduced by $36.47 \%$ and $44.7 \%$, respectively at severe infection (GI-5), while expected reductions were $38.7 \%$ and 46.55 , respectively.

The root-knot nematodes (Meloidogyne species) infect soybean plants in many parts of the world causing great loss in its yield. In USA, the combined crop 
loss due to Meloidogyne spp. and all other nematode species ranged from 106000 to 139000 tons during the years of 2003-2005 (Wrather and Koenning, 2006). Loss in yield was sometimes dramatic, reached $100 \%$ in yield of highly susceptible soybean cultivars (Riggs and Niblack, 1993). Finally, results showed that soybean is severely infected with the root-knot nematodes when is grown in sandy soil infected with nematodes and the expected loss in its yield is highly significant. So the producers and growers should take this fact in their consideration before make a decision of cultivation.

\section{References}

Barker K.R. (1985). Nematode Extraction and Bioassay, pp. 29-30. In: An Advanced Treatise on Meloidogyne. Vol 2 (Methodology). K.R. Barker, C.C. Carter and J.N. Sasser (eds). North Carolina State University Graphics, Raleigh, N.C.

Chaudhary K.K., Brhane D., Okube H., Zaid T. and Dagnew E. (2011). Distribution, frequency of occurrence and population density of root-knot nematode in Hamelmalo-Eritrea. African J. Microbiolog Research. 5: 56565661.

EI-Sherif A.G. and Ismail A.F.A. (2011). Role of certain biological measures in comparison with oxamyl for controlling Meloidogyne incognita infecting soybean. Egypt. J. Agronematol., 10(1): 49-63.

El-Sherif A.G., El-Gindi A.Y., Refaei A.R., El-Nagar M.M. and Salem H.M. (2012). Host suitability of five soybean cultivars to the root-knot nematode Meloidogyne incognita infection and reproduction under greenhouse conditions. Egypt. J. Agronematol. 11(1):72-79.

Goodey J.B., Franklin M.T. and Hooper D.J. (1965). The nematode parasites of plants catalogued under their hosts. C.A.B. Farnham royal, Bucks, England. $214 \mathrm{pp}$.

Harry E.S. and Kown T.W. (1987). Soybean utilization. Van Nostrand Reinhdd company, New York, 346 pp.

Hunt D.J. and Handoo Z.A. (2009). Taxonomy, Identification and Principal Species. Pp.55-97. In: Root Knot Nematodes. R.N. Perry, M. Moens, J.L. Start. (eds). CABI, Wallingford, UK.

Ibrahim I.K.A (2011). Soybean Nematodes. pp. 121-125. In: Nematode parasites of field crops (diseases and control). Monchaat El-Maaref, Alexandria, Egypt.

Jepson S.B. (1987). Identification of root-knot nematodes (Meloidogyne species). CAB International, Wallingford, UK. 
Kella A.M., El-Sayed S.A. and El-Shennawy R.Z. (2011). Survey, identification and control of nematodes and fungi infecting soybean plants at Minufiya governorate, Egypt. J. Agronematol., 10 (1): 22-36.

Kinloch R.A. (1974). Response of soybean cultivars to nematicidal treatments of soil infested with Meloidogyne incognita. Journal of Nematology, 6: 7-211.

Minton N.A., Parker M.B., Brooks O.L. and Perry C.E. (1979). Effect of nematicide placement on nematode populations and soybean yield. Journal of Nematology, 11(2): 150-155.

Neler J., Wassermann W. and Kunter M.H (1985). Applied linear statistical models. Regression, analysis of variance and experimental design $2^{\text {nd }} \mathrm{Ed}$. Richard D. Irwin Inc. Homewood Illionois .

Netscher C. and Sikora R.A. (1990). Nematode Parasites of Vegetables. Pp. 237383. In: Plant Parasitic Nematodes in Subtropical and Tropical Agriculture. M.Luc, R.A. Sikora and J Bridge (eds) C.A.B. International Institute of Parasitology, Uk.

Noel G.R. (2008). IPM of soybean cyst nematode in the USA. pp. 119-126. In: Integrated Management and Biocontrol of Vegetable and Grain Crops Nematodes. A. Ciancio and K.G. Mukerji (eds). Springer. Dordrecht, the Netherland.

Riggs R.D. and Niblack T.L. (1993). Nematode parasites of oilseed crops and grain legumes pp.209-258. In: Plant Parasitic Nematodes in Temperate Agriculture. K. Evans, D.L. Trudgill, J.M. Webster (eds). CAB International.

Schmitt D.P. and Noel G.R. (1984). Nematode parasites of soybean, pp. 13-59. In: Plant and insect nematodes, Nickel W.R. (ed). New York, Marcl Dekker.

Seinhorst J.W. (1965). The relation between nematode density and damage to plants. Nematologica 11:137-154.

Siddiqi M.R. (2000). Tylenchida parasites of plants and insects. CAB International, Wallingford, UK.

Singh S.R., Rachine K.O. and Dashiell K.E. (1987). Soybean for the tropics. Research, Production and Utilization. Chichesten, New York, Brisbane, Toronto, Singapore. pp.230.

Wrather J.A. and Koenning S.R. (2006). Estimates of disease effects on soybean yields in the United State 2003 to 2005. Journal of Nematology 38(2): 173.

Wrather J.A., Koenning S.R. and Anderson T.R. (2003). Effects of diseases on soybean yield in the United States and Ontario (1999-2002). Plant Health progress doi:10.1094/PHP-2003-0325-01-RV. 
الخسارة المتوقعة في محصول فول الصويا بسبب نيماتودا تعقد الجذور تحت ظروف التربة الرملية (Meloidogyne arenaria)

$$
\begin{aligned}
& \text { أحمد محمد كريم**، ومعوض محمد محمد محمد } \\
& \text { * ق أمراض النبات، المركز القومي للبحوث، الدقي، جيزة، مصر. } \\
& \text { الملخص العبي }
\end{aligned}
$$

في أثناء الموسم الزراعي الصيفي لعام 10 • Y، تم دراسة العلاقة بين شدة الإصابة (درجة التعقد الجذري) بنيماتودا تعقد الجذور من النوع Meloidogyne arenaria وبين نمو محصول فول الصويا المنزرع في أرض رملية مصابة طبيعًً بالنيماتودا، وذلك لبيان نوع ودرجة الارتباط بينهما وكذا حساب الفاقد المتوقع في المحصول. تم اختيار حوالي (• ل. (1) نبات

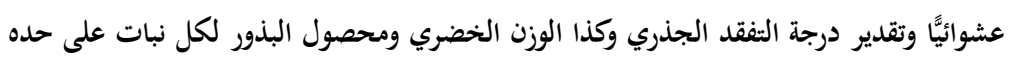

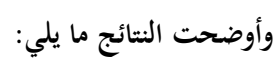
ا- العلاقة بين وزن كل من المجموع الخضري والبذور وبين درجة الإصابة كانت سالبة بمعامل

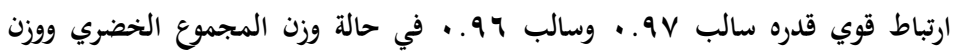

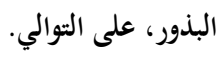

r- كمية الفاقد التجريبي (المشاهد) في الوزن الخضري وفي وزن البذور في حالة الإصابة

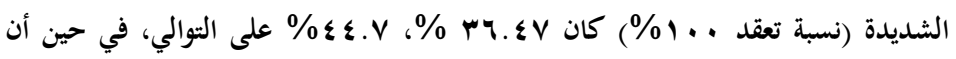

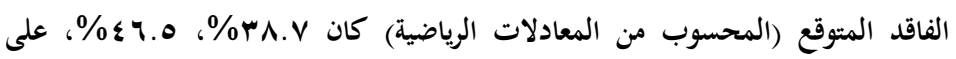
التوالي، أي أعلى من الفاقد المشاهد. الكلمات الدالة: فول الصويا، نيماتودا تعقد الجذور، نسبة الفاقد، الضرر. 